\title{
Kebijakan Pemerintah Indonesia Untuk Membebaskan Narapidana Sebagai Upaya Pencegahan Penyebaran Covid-19 Di Lapas
}

\author{
Fauziyah, Vidya Ayu Herawati \\ Universitas Muhammadiyah Jember \\ E-mail : fauziyah@unmuhjember.ac.id. \\ Diterima: Desember 2020 ; Dipublikasikan Januari 2021
}

\begin{abstract}
ABSTRAK
Dunia sedang berjuang untuk mengatasi masalah yang ada saat ini yaitu COVID-19. Diketahui bahwa COVID-19 menular dari manusia ke manusia karena itulah penyebarannya sangat cepat dan harus segera dikendalikan. Indonesia pun tak luput dari penyebaran COVID19 ini. Perseberannya semakin cepat dan mengakibatkan banyak korban berjatuhan. Pemerintah juga banyak mengeluarkan kebijakan terkait pengananan COVID-19 seperti menetapkan masa tanggap darurat nasional. Salah satu upaya lain pemerintah untuk menghentikan penyebaran COVID-19 di Indonesia adalah dengan mengeluarkan kebijakan pembebasan bersyarat Narapidana untuk mencegah penyebaran COVID-19 di lingkungan Lapas. Dalam tulisan ini akan dibahas mengenai dasar hukum yang digunakan pemerintah untuk mengeluarkan kebijakan pembebasan narapidana demi mencegah COVID-19 menyebar di Lapas. Sudah patut atau tidak kebijakan ini dikeluarkan mengingat bahwa tidak serta merta pembebasan bersyarat bisa diberikan kepada Narapidana. Dalam tulisan ini menggunakan metode penelitian normatif-empiris melalui kebijakan yang dikeluarkan pemerintah. Dari kebijakan pemerintah yakni Menkumham yang mengeluarkan Peraturan Menteri Hukum dan HAM RI nomor 10 tahun 2020 perlu adanya analisa untuk menilai apakah langkah yang diambil pemerintah sejalan dengan upaya pencegahan penyebaran COVID-19 dan apa tolak ukur pemerintah dalam mengeluarkan kebijakan ini.
\end{abstract}

Kata Kunci: COVID-19, pembebasan bersyarat, Narapidana

\begin{abstract}
The world is struggling to overcome the current problem, namely COVID-19. It is known that COVID-19 is transmitted from human to human because of that its spread is very fast and must be controlled immediately. Indonesia also did not escape the spread of COVID-19. The acceleration was faster and resulted in many casualties. The government also issued many policies related to the handling of COVID-19 such as establishing a national emergency response period. One of the government's efforts to stop the spread of COVID-19 in Indonesia is to issue a prisoner parole policy to prevent the spread of COVID-19 in Penitentiary. In this paper, we will discuss the legal basis used by the government to issue prisoner release policies to prevent COVID-19 from spreading in prison. It is appropriate or not this policy was issued bearing in mind that not necessarily parole can be given to prisoners. In this paper using the normative-empirical research method through policies issued by the government. From the government policy namely Minister of Law and Human Rights which issued Minister of Law and Human Rights Regulation number 10 of 2020 need an analysis to assess whether the steps taken by the government are in line with efforts to prevent the spread of COVID-19 and what the government benchmarks in issuing this policy. Keywords: Covid-19, parole prisioners
\end{abstract}

\section{PENDAHULUAN}

Dunia saat ini sedang mengalami krisis yaitu krisis global akibat adanya virus yaitu COVID19. Penyakit Coronavirus 2019 (COVID-19) adalah penyakit menular yang disebabkan oleh sindrom pernapasan akut coronavirus 2 (SARS-CoV-2). Penyakit ini pertama kali diidentifikasi pada Desember 2019 di Wuhan, ibu kota provinsi Hubei China, dan sejak itu menyebar secara global, mengakibatkan pandemi koronavirus 2019 yang sedang berlangsung saat ini (Corona virus wikipedia: 2020) COVID-19 telah ditetapkan sebagai pandemi karena penyebaran yang luar biasa dan persebarannya hampir ada diseluruh dunia. Pandemi sendiri merupakan suatu wabah penyakit global. Menurut World Health Organization (WHO), pandemi dinyatakan ketika penyakit baru 
menyebar di seluruh dunia melampaui batas. (Fajri Anindya : 2020) Untuk itulah COVID-19 dikategorikan sebagai pandemi global.

Di Indonesia COVID-19 sudah menyebar dan peningkatan penyebarannya sungguh luar biasa hingga Indonesia menetapkan bahwa COVID-19 sebagai bencana non alam yang ada di Indonesia ( UU No. 24/2007) dan pemerintah menyatakan bahwa COVID-19 harus segera dipercepat penanganannya seperti pada Pasal 50 UU Nomor 24 tahun 2017 tentang penanggulangan bencana. Pasal tersebut mengatur bahwa "dalam hal status keadaan darurat telah ditetapkan, Badan Nasional Penanggulangan Bencana dan badan penanggalangan bencana daerah mempunyai kemudahan akses yang meliputi : a. Pengerahan sumber daya manusia ; b. Pengerahan peralatan :c. Pengerahan logistik ;d. imigrasi, cukai dan karantina ; f. Pengadaan barang/jasa ; g. Pengelolaan dan pertanggung jawaban uang dan/atau barang ; h. Penyelamatan; dan i. Komando untuk memerintahkan sektor/lembaga." Dengan dasar pasal di atas pemerintah mengambil kebijakan untuk karantina mandiri bagi masyarakat yang belum terinfeksi COVID-19 untuk memutus mata rantai penyebaran COVID-19. Kebijakan ini tepat karena memang penyebaran COVID-19 lebih cepat di tempat ramai dan kerumunan yang jika dikeramaian tersebut ada orang yang positif COVID-19 maka yang lain mungkin dapat terpapar juga dan menyebarkan lebih luas ke orang lain.

Namun ada lagi kebijakan pemerintah terhadap upaya mencegah COVID-19 menyebar di lingkungan Lapas dengan membebaskan narapidana. Narapidana adalah terpidana yang menjalani pidana hilang kemerdekaan di lembaga pemasyarakatan. (Permenkumham RI No. 10/2020). Sedangkan Lembaga pemasyarakatan adalah sebagai tempat pembinaan dengan tujuan agar narapidana dapat kembali menjadi warga masyarakat yang baik yang menyadari segala kesalahannya serta dapat kembali ke dalam masyarakat dengan menjadi manusia yang baik. Pembinaan narapidana adalah suatu sistem, maka pembinaan narapidana mempunyai bebrapa komponen yang bekerja saling berkaitan untuk satu tujuan. (CI Harsono: 1995). Pemerintah mengambil langkah membebaskan napi sekitar 30 ribuan. Kementerian Hukum dan HAM akan membebaskan sekitar 30 ribu narapidana dan anak dari lembaga pemasyarakatan, rumah tahanan negara, serta Lembaga Pembinaan Khusus Anak (LPKA). Hingga 11 April 2020 total sudah 36.554 narapidana dan anak yang dibebaskan dari Lapas. (CNN Indonesia, April 2020)

Padahal kenyataanya sampai saat ini belum ada kabar beredar bahwa ada narapidana yang positif COVID-19. Jelas kebijakan ini tidak sejalan dengan kenyataan yang ada. Pemerintah beranggapan bahwa dengan telah ditetapkannya Covid-19 sebagai bencana nasional nonalam, pemerintah Indonesia menilai perlu untuk melakukan langkah cepat sebagai upaya penyelamatan terhadap tahanan dan warga binaan pemasyarakatan dengan cara pengeluaran dan pembebasan melalui asimilasi dan integrasi. Upaya ini mempertimbangkan sisi kemanusiaan dan pencegahan menyebarnya Covid-19 di Lapas yang apabila tidak segera di ambil langkah pencegahan maka berakibat buruk dan sulit diselesaikan nantinya. Lapas di Indonesia sebagian besar melebihi kapasitas karena banyaknya pelaku tindak pidana karena itulah langkah pembebasan ini perlu dilakukan.

Pembebasan narapidana secara asimilasi adalah proses pembinaan narapidana yang dilaksanakan dengan membaurkan narapidana dalam kehidupan masyarakat. (Permenkumham No. 10/2020). Yang berarti narapidana akan dibebaskan sebelum berakhir masa pidananya. Namun karena merebaknya Covid-19 dan pembebasan narapidana dari lapas semakin membuat masyarakat resah. Tidak dapat dipungkiri bahwa berkembang stigma negatif di masyarakat bahwa narapidana adalah sampah masyarakat ini merupakan frasa yang buruk terkait pemberian julukan untuk mantan penghuni Lapas. Serta mantan narapidana dianggap berkemungkinan besar akan melakukan tindak pidana lagi. Pemerintah telah mengambil resiko tinggi untuk membebaskan ribuan napi dengan ini pemerintah mengambil tindakan tegas kepada para narapidana yang telah dibebaskan jika mengulangi lagi tindak pidana maka hukumannya akan semakin berat. Artikel ini membahas Pembebasan Narapidana apakah bisa dilakukan karena COVID-19 dan bagaimana dampaknya, Apa dasar hukum kebijakan pemerintah dengan mengeluarkan Peraturan Menteri Hukum dan HAM RI nomor 10 tahun 2020 sebagai syarat untuk dapat membebaskan Narapidana dan anak, Bagaimana prosedur dan syarat narapidana untuk mendapatkan pembebasan bersyarat karena Covid-19. 


\section{METODE PENELITIAN}

Metode penelitian yang digunakan dalam penulisan makalah ini adalah metode pendekatan normatif-empiris. Penelitian hukum normatif-empiris adalah penelitian hukum mengenai pemberlakuan ketentuan hukum normatif ( kodifikasi, undang-undang atau kontrak) secara in action pada setiap peristiwa hukum tertentu yang terjadi dalam masyarakat. (Abdulkadir Muhammad, 2004).

Penelitian hukum normatif adalah penelitian studi dokumen karena penelitian ini dilakukan atau ditujukan hanya apada peraturan-peraturan yang tertulis atau bahan-bahan hukum yang lain. ${ }^{1}$ (Soerjono Soekanto, dan Sri Mamudji: 2004) Pada intinya penelitian yang dilakukan dengan cara meneliti data sekunder yang terdiri dari bahan hukum primer, bahan hukum sekunder dan bahan hukum tertier.

Penelitian hukum empiris yaitu penelitian yang dilakukan langsung dari masyarakat sebagai sumber pertama dengan melalui penelitian lapangan, penelitian hukum empiris memberikan arti penting terhadap analisis yang bersifat kuantitatif dan empiris, sehingga langkah dan desain teknis penelitian tersebut mengikuti pola penelitian dari ilmu sosial khususnya ilmu sosiologis (socio-legal research). (Peter Mahmud Marzuki, 2010).

\section{Bahan Hukum}

Bahan hukum yang digunakan dalam penulisan karya tulis ilmiah ini adalah data sekunder yang meliputi bahan hukum primer, bahan hukum sekunder dan bahan hukum tersier, yaitu:

1. Bahan hukum primer yaitu bahan hukum yang bersifat autoritatif atau mengikat ${ }^{2}$. (Peter Mahmud, 2010) Bahan hukum ini diperoleh melalui peraturan perundang-undangan yang berkaitan dengan permasalahan yang dibahas, yaitu :

1. Undang-Undang Dasar Negara Republik Indonesia tahun 1945

2. Undang-Undang Nomor 12 tahun 1995 tentang pemasyarakatan.

3. Undang-Undang Nomor 24 tahun 2007 tentang penanggulangan bencana.

4. Peraturan Menteri Hukum dan HAM RI nomor 3 tahun 2018 tentang syarat dan tata cara pemberian remisi, asimilasi, suti mengunjungi keluarga, pembebasanbersyarat, cuti menjelang bebas dan cuti bersyarat.

5. Peraturan Menteri Hukum dan HAM RI nomor 10 tahun 2020 tentang syarat pemberian asimilasi dan hak integrasi bagi narapidana dan anak dalam rangka pencegahan dan penanggulangan penyebaran COVID-19.

6. PP Nomor 32 tahun 1999 tentang syarat dan tata cara pelaksanaan hak warga binaan pemasyarakatan.

7. PP Nomor 99 tahun 2012 tentang perubahan kedua atas PP Nomor 32 tahun 1999 tentang syarat dan tata cara pelaksanaan hak warga binaan pemasyarakatan.

2. Bahan hukum sekunder yaitu bahan hukum yang mendukung bahan hukum primer (Ibid), bahan hukum ini berupa rancangan undang-undang, buku-buku, jurnal maupun literatur yang berkaitan.

3. Bahan hukum tersier yaitu bahan hukum yang mendukung bahan hukum primer maupun sekunder, bahan hukum ini diperoleh melalui internet, ensiklopedia dan kamus.

\section{Teknik Pengambilan Bahan Hukum}

Bahan hukum primer dikumpulkan melalui inventarisasi peraturan perundang-undangan dan peraturan lainnya yang terkait dengan permasalahan yang dibahas. Sedangkan bahan hukum sekunder diperoleh melalui studi pustaka dengan membaca dan mempelajari hasil karya ilmiah para ahli berupa literatur sehingga dapat mendukung dan melengkapi dalam membahas masalahmasalah yang timbul dalam rangka penyusunan penulisan karya tulis ilmiah ini. Sebagai pelengkap yaitu bahan hukum tersier untuk melengkapi dalam pengaturan bahasa dan sumber-sumber yang belum jelas. 


\section{Analisis Bahan Hukum}

Setelah semua bahan hukum terkumpul, kemudian dilakukan pengolahan bahan hukum sehingga dapat menghasilkan kesimpulan dan gambaran yang jelas dari suatu permasalahan yang dibahas. Analisis bahan hukum yang dipergunakan dalam penulisan karya tulis ilmiah ini adalah analisis kualitatif, yaitu cara memperoleh gambaran akan suatu permaslahan dengan tidak didasarkan pada angka-angka tetapi berdasarkan UU dan peraturan yang berlaku dan dihubungkan dengan kenyataan yang terjadi di masyarakat. Selanjutnya dapat ditarik kesimpulan dengan metode deduktif yaitu menyimpulkan pembahasan dari hal-hal yang bersifat umum ke hal-hal yang bersifat khusus.

\section{HASIL DAN PEMBAHASAN}

\section{Pembebasan Narapidana Ditengah Merebaknya Covid-19 Di Indonesia}

Berbagai macam upaya dilakukan pemerintah untuk menekan penyebaran Covid-19 di Indonesia seperti lockdown di daerah-daerah tertentu, kebijakan PSBB (pembatasan sosial berskala besar) dan yang akan dibahas dalam pembahasan ini adalah kebijakan mengenai pembebasan narapidana ditengah merebaknya Covid-19. Menteri Hukum dan HAM Yasonna Laoly telah mengeluarkan keputusan Menteri dan menandatangani Kepmen Nomor M.HH-19.PK.01.04.04 tahun 2020 tentang pengeluaran dan pembebasan narapidana dan anak melalui asimilasi dan integrasi dalam rangka pencegahan dan penanggulangan penyebaran COVID-19. Memberikan kebijakan pembebasan bersyarat kepada seseorang yang terbukti telah melakukan tindak pidana atau kejahatan bukanlah perkara yang mudah. Namun langkah ini diambil pemerintah bukan tanpa sebab, mengingat tingginya tingkat hunian di Lapas yang semakin hari semakin bertambah bukan mengalami penurunan. Untuk menekan tingkat hunian yang tinggi inilah perlu adanya kebijakan pembebasan bersyarat sebagai upaya lain pencegahan penyebaran Covid-19.

Dengan disetujuinya keputusan menteri No 10 tahun 2020 maka pelaksanaannya juga sudah dilakukan pemerintah. Dalam pelaksanaanya narapidana dan anak yang telah dibebaskan tetap mendapat pengawasan dari balai pemasyarakatan/ Lembaga Pemasyrakatan (Lapas). Jika diketahui melakukan tindak pidana lagi maka akan diberikan hukuman yang lebih berat. Adapun ketentuan yang diberikan terkait pembebasan narapidana yang dibebaskan melalui integrasi (pembebasan bersyarat, cuti bersyarat, dan cuti menjelang bebas ) dalam Pasal 1 angka 5 Peraturan Menteri Hukum dan HAM RI nomor 10 tahun 2020. Narapidana dan anak yang mendapatkan pembebasan karena asimilasi dan integrasi semua merupakan pelaku tindak pidana umum. Karena tidak semua narapidana bisa mendapatkan pembebasan seperti narapidana tindak pidana terorisme, narkotika yang mendapat pidana diatas 5 (lima) tahun, kejahatan HAM berat, kejahatan terhadap keamanan negara dan korupsi.

Dengan adanya kebijakan pembebasan narapidana ini, pemerintah diharapkan juga mempertimbangkan bagaimana yang terjadi dimasyarakat akibat kebijakan ini, diatur dalam Pasal 2 angka 3 Permenkumham Nomor 3 tahun 2018. Ketika masyarakat sudah resah karena adanya Covid19 dan terakumulasi dengan keresahan karena stigma negatif terkait narapidana. Situasi akan semakin pelik bagi mantan narapidana dan bagi pemerintah seharusnya. Dengan kehadiran mantan narapidana di tengah masyarakat masih dianggap tabu dan membawa atmosfer kelam bagi lingkungan masyarakat apalagi dengan jumlah narapidana yang terbilang tidak main-main yaitu 30 ribuan. Eks Napi sering mengalami masalah diskriminasi sosial hingga sulit mendapatkan pekerjaan yang layak. Terkadang karena inilah ada eks napi yang mengulangi lagi tindak pidana. Peran pemerintah disini dirasa belum cukup untuk melindungi eks napi dari tekanan masyarakat dan kondisi ekonomi yang semakin memburuk akibat adanya Covid-19. Jika dalam Lapas Narapidana masih mendapatkan Upah yang digunakan untuk memenuhi keperluan selama di Lapas atau untuk biaya pulang yang diatur dalam Pasal 29 Undang-Undang Nomor 32 tahun 1999 sebagai bagian dari haknya di Lapas. Jika sudah keluar Lapas maka tanggung jawab kebutuhan ekonomi akan menjadi tanggung jawab eks napi itu dan bukan lagi negara. Tentu dalam mengambil kebijakan pembebebasan ini pemerintah tidak mengharapkan bahwa tekanan yang ada akan menyebabkan tindak kriminalitas yang berulang dan membuat eks napi yang di bebaskan akan kembali masuk ke Lapas. 
Kebijakan pembebasan napi oleh pemerintah memang tidak seharusnya dieksekusi dan dilaksanakan dengan tergesa-gesa walaupun penyebaran Covid-19 yang semakin cepat namun masih belum memasuki lingkungan Lapas . Seharusnya dengan begitu Pemerintah masih mempertimbangkan dampak lanjutan yang matang dan komprehensif. Negara harus adil dalam memperlakukan eks napi karena bagaimanapun juga setiap kebijakan akan memiliki dampak baik positif maupun negatif. Pemerintah diharapkan bisa memberikan solusi bagi kehidupan baru eks napi di lingkungan masyarakat.Namun pengecualiaan untuk kebijakan ini bagi napi terorisme, narkotika dan korupsi. Disini pemerintah bisa menerapkan Pasal 38 UU nomor 32 tahun1999 yang menjelaskan bahwa narapidana dan anak yang mendapatkan asimilasi ada pembinaan atau pembimbingan kegiatan diluar Lapas yang dilakukan oleh petugas Lapas dengan pengawasan Kepolisian. Jika yang mendapatkan kebebasan bersyarat juga diberi bimbingan oleh Bapas secara berkala dan berkesinambungan menurut pasal 45 UU nomor 32 tahun 1999 serta diatur dalam pasal 6 angka 3 huruf b UU Nomor 12 tahun 1995 tentang pemasyarakatan.

Bimbingan yang dilakukan oleh badan pemasyarakatan diharapkan bisa menjangkau daerahdaerah yang tidak terjangkau dalam hal transportasi agar tercapai kesama rataan dalam penerimaan bimbingan bagi eks napi yang telah bebas dari Lapas. Karena hal yang dikeluhkan eks napi dalam bimbingan adalah biaya perjalanan dan tempat yang masih belum bisa dijangkau oleh semua eks napi. Untuk itu bantuan dari pemerintah diharapkan bisa membantu eks nai sehingga tercapai tujuan untuk memberdayakan eks napi dan bisa mengurangi terjadinya kriminalitas. Sehingga upaya pembebasan napi yang dikeluarkan pemerintah tidak sia-sia. Tidak hanya pemerintah yang diharap membantu dan mengatasi masalah ini melainkan kita sebagai warga negara Indonesia harus bahu membahu menyelamatkan negara ini dari Covid-19 dan dampak lain dari kebijakan pemerintah.

\section{Dasar Hukum Kebijakan Pemerintah Permen Hukum Dan Ham Ri Nomor 10 Tahun 2020}

Dalam mengambil kebijakan ini Pemerintah yaitu Menteri Hukum dan HAM mempertimbangkan beberapa hal yaitu lembaga kemasyarakatan, lembaga pembinaan khusus anak dan rumah tahanan negara yang tertutup dan memiliki tingkat hunian tinggi sehingga rentan terhadap penyebaran Covid-19. Sebagai dasar hukumnya yaitu yaitu pasal 17 ayat 3 UUD NRI 1945 yang menjelaskan bahwa menteri membidangi urusan tertentu dalam pemerintahan. Oleh sebab itu Menteri Hukum dan HAM memiliki wewenang mengurusi kebijakan terkait pembebasan bersyarat dengan mengeluarkan Permen Hukum dan HAM nomor 10 tahun 2020.

Terkait dengan dikeluarkannya Keputusan Presiden RI nomor 11 tahun 2020 tentang penetapan kedaruratan kesehatan masyarakat Covid-19 yang didalamnya menyatakan bahwa wajib adanya upaya penanggulangan terkait Covid-19. Narapidana selaku masyarakat yang menjalani masa pidana di Lapas juga mendapat pembebasan terkait upaya penanggulangan Covid-19. Dasar hukum lain adalah Pasal 36 Undang-Undang Nomor 32 tahun 1999 yang menjelaskan bahwa narapidana dan anak berhak mendapatkan asimilasi. Dengan adanya dasar hukum diatas kebijakan Menkumham tidak bertentangan dengan peraturan perundang-undangan lainnya.

\section{Prosedur Dan Syarat Pembebasan Bersyarat Narapidana Karena Covid-19}

Pembebasan bersyarat adalah salah satu kebijakan pemerintah untuk mencegah penyebaran Covid-19 di Lapas. Namun ada syarat dan prosedur yang harus dipenuhi narapidana untuk mendapatkan pembebasan bersyarat dengan asimilasi dan integrasi seperti yang diatur dalam permenkumham nomor 10 tahun 2020. Adapun syarat narapidana yang akan diberikan asimilasi dalam Pasal 2 angka 2 Permenkumham Nomor 10 tahun 2020 yaitu :

a. berkelakuan baik dibuktikan dengan tidak sedang menjalani hukuman disiplin dalam kurun waktu 6 (enam) bulan terakhir;

b. aktif mengikuti program pembinaan dengan baik; dan

c. telah menjalani $1 / 2$ (satu per dua) masa pidana.

Semua itu harus dibuktikan dengan melampirkan dokumen seperti yang diatur dalam Pasal 4 Permenkumham Nomor 10 tahun 2020 yaitu :

a. fotokopi kutipan putusan hakim dan berita acara pelaksanaan putusan pengadilan; 
b. bukti telah membayar lunas denda dan uang pengganti sesuai dengan putusan pengadilan atau melaksanakan subsidaer pengganti denda dijalankan di rumah dalam pengawasan oleh Kejaksaan dan Balai Pemasyarakatan;

c. laporan perkembangan pembinaan yang ditandatangani oleh Kepala Lapas;

d. salinan register F dari Kepala Lapas;

e. salinan daftar perubahan dari Kepala Lapas; dan

f. surat pernyataan dari Narapidana tidak akan melarikan diri dan tidak melakukan perbuatan melanggar hukum.

Sedangkan syarat untuk narapidana yang akan diberikan pembebasan bersyarat dan cuti menjelang bebas menurut pasal 9 permenkumham nomor 10 tahun 2020 adalah :

a. telah menjalani masa pidana paling singkat $2 / 3$ (dua pertiga), dengan ketentuan $2 / 3$ (dua per tiga) masa pidana tersebut paling sedikit 9 (sembilan) bulan;

b. berkelakuan baik selama menjalani masa pidana paling singkat 9 (sembilan) bulan terakhir dihitung sebelum tanggal 2/3 (dua per tiga) masa pidana;

c. telah mengikuti program pembinaan dengan baik, tekun, dan bersemangat; dan

d. masyarakat dapat menerima program kegiatan pembinaan Narapidana.

Syarat lainnya adalah petugas pemasyarakatan atau tim pengamat Lapas mendata narapidana yang akan diusulkan untuk mendapatkan pembebasan bersyarat dengan integrasi dan asimilasi. Lalu jika disetujui oleh Kepala Lapas/LKPA langsung menyampaikan usul tersebut kepada direktur Jendral dengan tembusan kepada kepala kantor wilayah. Jika sudah disetujui juga maka bisa dikeluarkan keputusan pemberian pembebasan bersyarat.

Dalam pasal 23 ayat 2 permenkumham nomor 10 tahun 2020 menjelaskan bahwa peraturan ini berlaku selama masa kedaruratan terhadap penanggulangan Covid-19 sampai masa yang ditetapkan oleh pemerintah berakhir jadi jika masa penanggulangan Ccovid-19 berakhir kebijakan pembebasan narapidana sebagai upaya penanggulangan Covid-19 tidak bisa lagi dilakukan.

\section{Kesimpulan}

\section{KESIMPULAN DAN SARAN}

Dengan adanya upaya penanggulangan Covid-19 pemerintah mengeluarkan kebijakan pembebasan narapidana, pemerintah diharapkan juga mempertimbangkan bagaimana yang terjadi dimasyarakat akibat kebijakan ini, diatur dalam Pasal 2 angka 3 Permenkumham Nomor 3 tahun 2018. Disini pemerintah bisa menerapkan Pasal 38 UU nomor 32 tahun1999 yang menjelaskan bahwa narapidana dan anak yang mendapatkan asimilasi ada pembinaan atau pembimbingan kegiatan diluar Lapas yang dilakukan oleh petugas Lapas dengan pengawasan Kepolisian. Jika yang mendapatkan kebebasan bersyarat juga diberi bimbingan oleh Bapas secara berkala dan berkesinambungan menurut Pasal 45 UU nomor 32 tahun 1999 serta diatur dalam Pasal 6 angka 3 huruf b UU Nomor 12 tahun 1995 tentang pemasyarakatan. Jadi bisa memberikan keadilan dan ketentraman bagi masyarakat serta kenyamanan bagi eks napi agar tidak lagi melakukan tindak pidana. Selain mengeluarkan kebijakan pemerintah juga harus memikirkan dampak lanjutan dari kebijakan tersebut serta solusi terbaik yang dapat diambil untuk menanggulangi penyebaran Covid19 sehingga tidak ada lagi pihak yang dirugikan dari adanya kebijakan yang yang dikeluarkan. Serta dengan merebaknya virus Covid-19 diharapkan tidak ada kebijakan yang hanya akan menguntungkan pihak yang berkepentingan dan merugikan masyarakat. Seperti adanya wacana untuk membebaskan napi koruptor pembebasan napi harus berdasarkan peraturan perundangundangan dan memikirkan rasa keadilan masyarakat. Tidak serta merta pembebasan bisa dilakukan karena ada syarat dan prosedur yang harus dipenuhi yang sudah diatur dalam Permenkumham nomor 10 tahun 2020.

\section{Saran}

Menurut peneliti, dalam mengatasi masalah Covid-19 di Indonesia. Pemerintah dan masyarakat diharapkan berkoordinasi secara terpadu agar tercipta keseimbangan dan tercipta solusi yang baik bagi semua pihak. Khususnya terkait kebijakan pembebasan narapidana pemerintah seakan-akan tergesa-gesa dalam pengambilan keputusan dan pelaksanaan kebijakan ini. Sehingga 
efeknya masyarakat menjadi resah sedangkan pemerintah tidak memberikan solusi untuk eks napi untuk menjalani kehidupan barunya dilingkungan masyarakat. Sehingga ada kemungkinan besar eks napi mengulangi lagi tindak kriminalitas. Seperti yang diketahui dalam kenyataan di masyarakat saat ini tanpa ada pembebasan napi pun tingkat kriminalitas semakin bertambah karena akibat dari adanya Covid-19 yang membuat tekanan dalam perekonomian ditambah lagi pembebasan eks napi yang belum dapat diterima dengan baik di masyarakat karena stigma negatifnya. Maka perlu solusi seperti bimbingan dan pembinaan berkelanjutan untuk eks napi dan penyuluhan untuk masyarakat agar tidak melakukan diskriminasi pada eks napi. Semoga saran ini bisa membantu dan dapat terwujud demi ketertiban, keamanan dan kelangsungan hidup berbangsa dan bernegara.

\section{DAFTAR PUSTAKA}

Abdulkadir Muhammad.( 2004). Hukum dan Penelitian Hukum. Bandung: Citra Aditya Bakti.

Achmad Soemadipradja, R dan Romli Atmasasmita.(1979). Sistem Pemasyarakatan di Indonesia, cet.1, Jakarta: Badan Pembinaan Hukum Nasional.

Andriana, (2009). Peran BAPAS Dalam Pembimbingan KlienPemasyarakatan Yang Menjalani Cuti Menjelang Bebas. Skripsi Fakultas Hukum Universitas Muhammadiyah Surakarta.

Arifin, HM. (1992). Bimbingan dan Konseling, Jakarta : Universitas Terbuka.

Bahrudin. (2014). Peranan Kejaksaan Dalam Melakukan Pengawasan Terhadap Narapidana Yang Memperoleh Pembebasan Bersyarat (Studi di Kejaksaan Negeri Malang) . Jurnal Fakultas Hukum Universitas Brawijaya Malang.

Fajria Anindya Utami, "Warta ekonomi" diakses dari https://www.google.co.id/amp/s/amp.wartaekonomi.co.id/berita276620/apa-itu-pandemi, , pada tanggal 11 April 2020 pukul 9:41

Harun Sulianto (2018). Hak Narapidana Tindak Pidana Narkotika Untuk Memperoleh Pembebasan Bersyarat. JURNAL RECHTENS, Vol. 7, No. 1

https://en.m.wikipedia.org/wiki/Coronavirus_disease_diakses 11 April 2020 pukul 9:36

https://m.cnnindonesia.com/nasional/20200411155847-20-492629/kemenkumham-telah-bebaskan36554-napi-di-tengah-wabah-corona diakses tanggal 12 April 2020 pukul 19:31

Jufri, E.A. (2016). Pelaksanaan Asimilasi Narapidana Di Lembaga Pemasyarakatan Terbuka Jakarta. Jurnal Fakultas Hukum Universitas YARSI.

Kusuma , F.P. (2013). Implikasi Hak-Hak Narapidana Dalam Upaya Pembinaan Narapidana Dalam Sistem Pemasyarakatan. Jurnal Fakultas Hukum Universitas Sebelas Maret Surakarta.

Maskuri .(2010). Pembebasan Bersyarat Sebagai Upaya Pembinaan Narapidana

Karim, A. (2020). Endemic Rice Pulu'Mandoti Supports the Economy and Food Security at Salukanan Community During Covid-19 Global Pandemic Crisis. International Journal of Innovative Science and Research Technology, 5(9), 793-796.

Peraturan Menteri Hukum dan HAM RI Nomor 10 tahun 2020 tentang syarat pemberian asimilasi dan hak integrasi bagi Narapidana dan anak dalam rangka pencegahan dan penanggulangan penyebaran COVID-19.

Peraturan Menteri Hukum dan HAM RI Nomor 3 tahun 2018 tentang syarat dan Tata cara pemberian remisi, asimilasi, suti mengunjungi keluarga, pembebasanbersyarat, cuti menjelang bebas dan cuti bersyarat.

Peter Mahmud Marzuki. (2010). Penelitian Hukum. Jakarta : Kencana Prenada Media Group.

PP Nomor 32 tahun 1999 tentang syarat dan tata cara pelaksanaan hak warga binaan pemasyarakatan. 
PP Nomor 99 tahun 2012 tentang perubahan kedua atas PP Nomor 32 tahun 1999 tentang syarat dan tata cara pelaksanaan hak warga binaan pemasyarakatan.

Rizanizarli, Setiawan A. (2017). Pembebasan Bersyarat Terhadap Narapidana Anak (Suatu Penelitian pada Lembaga Pembinaan Khusus Anak Lhoknga Aceh Besar) Jurnal Ilmiah Mahasiswa Universitas Syiah Kuala.

Soerjono Soekanto, dan Sri Mamudji, Penelitian Hukum Normatif, Cetakan ke-8, PT. Raja Grafindo Persada, Jakarta, 2004.

Suteja, J. (2018). Efektivitas

Undang-Undang Dasar Negara Republik Indonesia tahun 1945.

Undang-undang Nomor 12 Tahun 1995 tentang Kemasyarakatan,

Undang-Undang Nomor 24 tahun 2007 tentang Penanggulangan Bencana.

Wulandari. (2016). Efektivitas Sistem Pembinaan Narapidana Di Lapas Terhadap Tujuan Pemidanaan. (Jurnal UNTAG Semarang).

Yunus, N.R. (2020). Kebijakan Covid-19, Bebaskan Narapidana Dan Pidanakan Pelanggar PSBB. Buletin hukum dan keadilan Vol. 4 No. 1. 